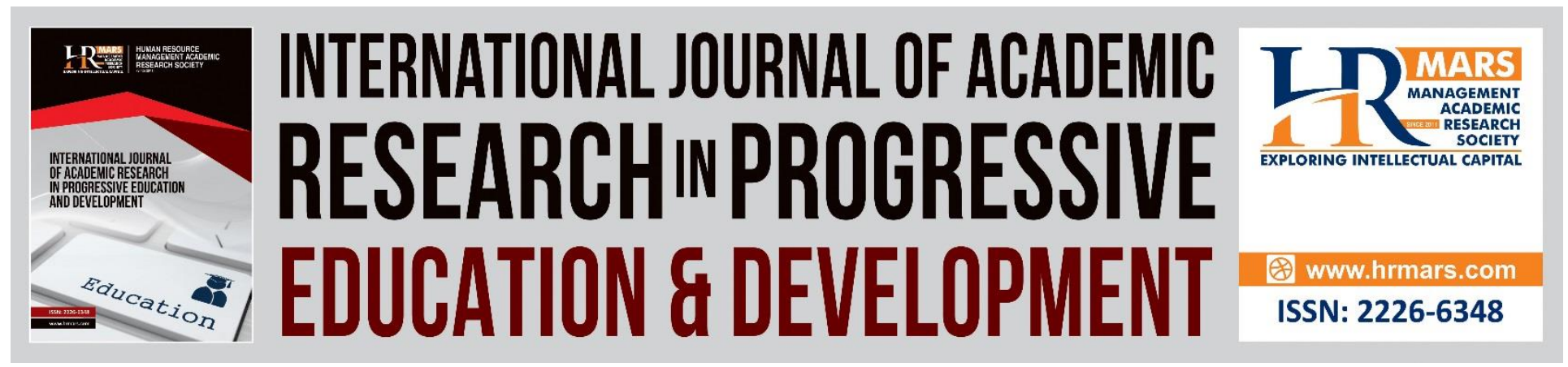

\title{
Organizational Culture and Leadership as Factors of Organizational Learning Capabilities
}

Norliya Ahmad Kassim, Kasmarini Baharuddin, Lokman Hakim Khalib

To Link this Article: http://dx.doi.org/10.6007/IJARPED/v7-i3/4365 DOI: $10.6007 /$ IJARPED/v7-i3/4365

Received: 11 June 2018, Revised: 25 June 2018, Accepted: 03 July 2018

Published Online: 20 July 2018

In-Text Citation: (Kassim, Baharuddin, \& Khalib, 2018)

To Cite this Article: Kassim, N. A., Baharuddin, K., \& Khalib, L. H. (2018). Organizational Culture and Leadership as Factors of Organizational Learning Capabilities. International Journal of Academic Research in Progressive Education and Development, 7(3), 268-277.

Copyright: (C) 2018 The Author(s)

Published by Human Resource Management Academic Research Society (www.hrmars.com)

This article is published under the Creative Commons Attribution (CC BY 4.0) license. Anyone may reproduce, distribute, translate and create derivative works of this article (for both commercial and non-commercial purposes), subject to full attribution to the original publication and authors. The full terms of this license may be seen at: http://creativecommons.org/licences/by/4.0/legalcode

Vol. 7, No. 3, July 2018, Pg. 268 - 277

Full Terms \& Conditions of access and use can be found at http://hrmars.com/index.php/pages/detail/publication-ethics 


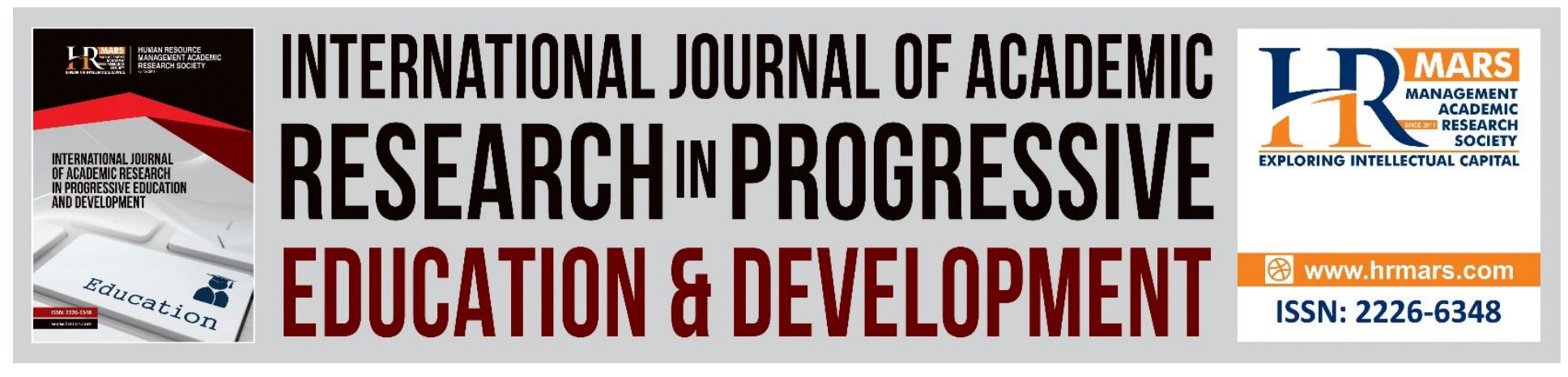

\title{
Organizational Culture and Leadership as Factors of Organizational Learning Capabilities
}

\author{
Norliya Ahmad Kassim, Kasmarini Baharuddin, Lokman Hakim \\ Khalib
}

Faculty of Information Management, Universiti Teknologi MARA, Puncak Perdana campus, Shah Alam, Selangor Darul Ehsan, Malaysia.

\begin{abstract}
The purpose of the study is to investigate the perceptions of Organizational Learning Capabilities (OLC) dimensions namely organizational culture and leadership among librarians in one public university library in Malaysia. In this pilot study, a research survey method using questionnaire was randomly distributed to 50 librarians of the library. The results of the survey were analyzed using the Statistical Package for the Social Sciences (SPSS). Descriptive statistics were analyzed using mean and standard deviation while inferential statistics used non-parametric test which were Mann-Whitney $U$ and Kruskal Wallis test. The results showed that respondents had positive perceptions on organizational culture (mean $=3.64$ ) and leadership (mean $=3.67$ ) as factors of organizational learning capabilities in their organization. Additionally, there was evidence of difference regarding organizational culture in terms of gender. The result is important to the organization to provide significant feedback on librarians' perception on organizational learning capabilities which is useful for the organization to enhance organizational learning.
\end{abstract}

Keywords: Organizational learning capabilities, Organizational Culture, Information Management

\section{Introduction}

Organizational learning has become a main concept that covers variation of topics in the organizations study of library (Kassim \& Shoid, 2013; Rowley, 2000). Moreover, the emerging of learning and knowledge in libraries will create and describe the concept of knowledge management and organizational learning capabilities (OLC). Organizational learning capability (OLC) can be defined as the ability of an organization to process knowledge, the ability to create, acquire, transfer and integrate knowledge and, also, to modify the behavior to reflect the new cognitive situation, with the aim at improving organizational performance (Jerez-Gomez, Cespedes-Lorente, \& Valle-Cabrera, 2005). Organizational learning or organizational learning capability is about the ability of one organization in order to apply the accurate and appropriate 
Vol. 7, No. 3, July 2018, E-ISSN: 2226-6348 @ 2018 HRMARS

management practices, its structures as well as the procedures which enhance, facilitate and encourage learning (Goh, 2003).

Organizational culture refers to a set of shared values that induces the organizational community to understand the functionality of the organization itself. At the same time, it also helps in guiding the way of thinking as well as the behavior of members. Organizational culture needs to be in the minds of all the members of the organization. A common similarity of the aforementioned definitions of organizational culture is that organizational culture can be seen as a set of underlying values and can influence the behavior of all the members of an organization and will socialize employees.

Leadership is a complex, multidimensional phenomena (DePree, 1989). Leadership has been defined as a behavior; a style; a skill; a process; a responsibility; an experience; a function of management; a position of authority; an influencing relationship; a characteristic; and an ability (Northouse, 2007). The term leadership has been defined and conceptualized in numerous ways and in accordance with different theories of leadership. Leadership is viewed as an important predictor and plays a central role. Leadership is a management function, which is mostly directed towards people and social interaction, as well as the process of influencing people so that they will achieve the goals of the organization (Skansi, 2000).

Shoid (2015) in his study identified eight dimensions of organizational learning capabilities to determine the knowledge performance among librarians in academic libraries which was adopted from the previous literature review. Each of the elements of the organizational learning capabilities has been cited by previous researchers (Shoid, Kassim, Salleh, 2011; Goh \& Richards, 1997, 2003; Neefe, 2001; Hishamuddin et al, 2010). These dimensions are (1) Systems thinking (2) Organizational culture (3) Leadership (4) Information Communication Technology (ICT) (5) Transfer of knowledge (6) Teamwork cooperation (7) Shared vision and mission (8) Employee's skills and competencies. Studies on organizational learning capabilities has also been cited in Shoid and Kassim (2015), Khalib, Kassim, Ghazali, Jaafar and Idris (2015), Shoid and Kassim (2014a; 2014b), Shoid, Kassim and Salleh (2011); Kassim and Shoid (2013), Chiva and Alegre (2005; 2008; 2009) and Chiva, Alegre and Lapiedra (2007).

The purpose of this study is to investigate the perceptions of Organizational Learning Capabilities (OLC) dimensions namely organizational culture and leadership among librarians at one public university in Malaysia. The specific objectives are:

1. To examine the librarians' perceptions on Organizational Learning Capabilities' dimensions namely organizational culture and leadership.

2. To compare organizational culture and leadership among gender and educational level.

\section{Methodology}

In this pilot study, the sample consists of 50 librarians in one public university library in Malaysia. Questionnaires were distributed personally to the respondents at their workplace of which 44 respondents had answered the questionnaire. This study adopted the questionnaires from the previous research and from various instruments such as OLC measurement instrument 
Vol. 7, No. 3, July 2018, E-ISSN: 2226-6348 @ 2018 HRMARS

(Chiva et al., 2007) and OLC dimensions measurement instrument (Shoid, Kassim \& Salleh, 2011; Shoid \& Kassim, 2012). The questionnaire was measured on a 1 (strongly disagree) through 5 (strongly agree) Likert Scale. For data analyses, descriptive and inferential statistical analyses were performed using the Statistical Package of Social Science (SPSS). The statistical tests of significant differences for the data used nonparametric techniques. Specifically, Mann-Whitney $U$ Test was carried out to measure the differences of variables between two independent groups, and Kruskal-Wallis test was used to examine the significant mean differences of variables among more than two groups.

\section{Results}

\section{Profile of respondents}

In this study, majority (29 or $65.9 \%$ ) of the respondents are female while $15(34.1 \%)$ are male. Slightly more than half ( 23 or $52.3 \%$ ) of the respondents are between $21-30$ years old age group, $10(22.7 \%)$ are in the age group of $31-40$ and $41-50$ years old. Only $1(2.3 \%)$ of the respondent is above 50 years old. Majority ( 36 or $81.8 \%$ ) of the respondents are middle management staff and $8(18.2 \%)$ are senior management staff. More than half (26 or $59.1 \%$ ) of the respondents have Bachelor degree, while 15 or $34.1 \%$ of the respondents have Master degree. Only 3 or $6.8 \%$ of the respondents are $\mathrm{PhD}$ holders. In terms of work experience, 28 (63.6\%) of the respondents have below 10 years of working experience, $12(27.3 \%)$ of the respondents have $11-20$ years of working experience and only $4(9.1 \%)$ of the respondents have above 21 years of working experience.

\section{Perception on Organizational Culture and Leadership}

This section presents the results of data analysis on the perceptions of respondents with regards to organizational culture and leadership. The perceptions of respondents were measured in a Likert scale of 1 to 5: (1) Strongly Disagree, (2) Disagree, (3) Quite Agree, (4) Agree and (5) Strongly Agree. In this study, the whole sample of 44 respondents consisting of librarians were used. 


\begin{tabular}{|c|c|c|}
\hline Statement & Mean & Std. Deviation \\
\hline $\begin{array}{l}\text { 1. Culture of practicing successful learning of other } \\
\text { departments and organization is practiced. }\end{array}$ & 4.00 & 0.715 \\
\hline $\begin{array}{l}\text { 2. Employees are encouraged to apply contribution } \\
\text { culture of new ideas. }\end{array}$ & 3.98 & 0.590 \\
\hline $\begin{array}{l}\text { 3. Management culture is to welcome new ideas } \\
\text { from staffs. }\end{array}$ & 3.95 & 0.608 \\
\hline $\begin{array}{l}\text { 4. Rewarding innovative ideas is one of the } \\
\text { leadership cultures. }\end{array}$ & 3.55 & 0.820 \\
\hline $\begin{array}{l}\text { 5. Culture of providing continuous feedbacks from } \\
\text { library communities is gained through } \\
\text { "knowledge-based action". }\end{array}$ & 3.36 & 0.750 \\
\hline $\begin{array}{l}\text { 6. It is a culture in organization as new staffs are } \\
\text { persuaded to question the organization's business } \\
\text { flow. }\end{array}$ & 3.36 & 0.865 \\
\hline \multirow[t]{2}{*}{$\begin{array}{l}\text { 7. Approval in writing for the introduction of new } \\
\text { work activities is not required for the } \\
\text { organizational culture. }\end{array}$} & 3.25 & 0.866 \\
\hline & 3.64 & 0.745 \\
\hline Overall mean for organizational culture & & \\
\hline
\end{tabular}

Table 1 displays the mean score and standard deviation (SD) of the perception on organizational culture. The mean score are arranged in decreasing order of size (diminishing degree of agreement). The overall mean score is 3.64 and the standard deviation is 0.745 which indicates that respondents quite agree with the statements on organizational culture. The mean scores for all items are between 4.00 to 3.25 and this indicates that they agree and quite agree with all the statements. Among the seven statements, the mean score is highest for culture of practicing successful learning of other departments and organization is practiced (mean=4.00) followed by employees are encouraged to apply contribution culture of new ideas (mean=3.98). Respondents rated the lowest to the statement on approval in writing for the introduction of new work activities is not required for the organizational culture (mean=3.25) yet it still denotes that respondents quite agree that the organization has reached the OLC with respect to organizational culture. On the whole, it can be said that respondents have positive perception that their organization has reached the level of OLC with regards to organizational culture. 
Vol. 7, No. 3, July 2018, E-ISSN: 2226-6348 @ 2018 HRMARS

Table 2: Mean Score for Leadership

\begin{tabular}{|c|c|c|}
\hline Statement & Mean & Std. Deviation \\
\hline 1. Leaders are open to change new ideas. & 3.84 & 0.834 \\
\hline 2. Leaders have the skills of sharing knowledge. & 3.84 & 0.713 \\
\hline $\begin{array}{l}\text { 3. Leaders always involve employees in making } \\
\text { important decision. }\end{array}$ & 3.82 & 0.896 \\
\hline $\begin{array}{l}\text { 4. Leaders always provide fast feedback in order } \\
\text { to identify the potential problems, overcoming } \\
\text { problems and opportunities. }\end{array}$ & 3.77 & 0.831 \\
\hline $\begin{array}{l}\text { 5. Leaders are always involved with the training } \\
\text { and activities with other employees. }\end{array}$ & 3.73 & 0.872 \\
\hline $\begin{array}{l}\text { 6. Innovative ideas that work are often rewarded } \\
\text { by leadership. }\end{array}$ & 3.52 & 0.902 \\
\hline $\begin{array}{l}\text { 7. Leaders are used to critism and accept it } \\
\text { without overly defensive. }\end{array}$ & 3.20 & 1.112 \\
\hline Overall mean for leadership & 3.67 & 0.880 \\
\hline
\end{tabular}

Table 2 shows the overall mean score is 3.67 and the standard deviation is 0.880 which indicates that respondents quite agree with the statements on leadership. The mean scores for all items are between 3.84 to 3.20 and this indicates that they quite agree with all the statements. Among the seven statements, the mean score is highest for leaders are open to change new ideas and leaders have the skills of sharing knowledge (mean=3.84 respectively) followed by leaders always involve employees in making important decision (mean=3.82). Respondents rated the lowest on the statement that leaders are used to critism and accept it without overly defensive (mean=3.20) nevertheless, it still signifies that they quite agree that the organization has reached the OLC with respect to leadership. In general, it can be presume that respondents have positive perception that their organization has reached the level of OLC with regards to leadership.

\section{Reliability Test Results}

The reliability test of the organizational culture and leadership were assessed using Cronbach's alpha which test how well a collection of items agrees with one another.

Table 3: Reliability Test Results

\begin{tabular}{|l|l|l|}
\hline Variables & Number of Statements & Cronbach's Alpha \\
\hline Organizational Culture & 7 & 0.829 \\
\hline Leadership & 7 & 0.932 \\
\hline
\end{tabular}

In this study, the results from the computed Cronbach's alpha showed that the variables are more than 0.70 in which the reliability level is acceptable. The reliability coefficient of OLC dimensions for organizational culture is good $(\alpha=0.829)$ and leadership is excellent $(\alpha=0.932)$. 
Vol. 7, No. 3, July 2018, E-ISSN: 2226-6348 @ 2018 HRMARS

\section{Normality Test Results}

Table 4: Normality Test Results

\begin{tabular}{|l|l|l|}
\hline Statement & Shapiro-Wilk Z statistics & $p$-value \\
\hline Organizational Culture & 0.916 & 0.003 \\
\hline Leadership & 0.901 & 0.001 \\
\hline
\end{tabular}

* Significant at 0.05

Normality test was conducted to determine whether the data were normally or not normally distributed. In this study, the Shapiro-Wilk Test was employed to assess the distribution of data. The results show that the values with respect organizational culture and leadership were not normally distributed (Table 4). Consequently, all statistical tests of significant differences for organizational culture and leadership will use nonparametric techniques.

\section{Comparing Perceived Organizational Culture and Leadership between Gender}

The emphasis of analysis in this section is on the differences of perceptions on the two dimensions of OLC, if any, between male and female respondents, and among respondents with different educational level,. Nonparametric test namely Mann-Whitney U Test and Kruskal-Wallis Test were carried out in this analysis because the data were not normally distributed.

Table 5: Summary Statistics of Mann-Whitney U Test on OLC Dimensions between Male and Female Respondents

\begin{tabular}{|c|c|c|c|c|c|c|}
\hline Item & $\begin{array}{l}\text { Mean } \\
\text { Male }\end{array}$ & Rank & $\begin{array}{l}\text { Mean Rank } \\
\text { Female }\end{array}$ & $\begin{array}{l}\text { Mann- } \\
\text { Whitney U }\end{array}$ & z-value & $p$-value \\
\hline $\begin{array}{l}\text { Organizational } \\
\text { Culture }\end{array}$ & 16.20 & & 25.76 & 123.000 & -2.373 & $0.018^{*}$ \\
\hline Leadership & 18.63 & & 24.50 & 159.500 & -1.474 & 0.141 \\
\hline
\end{tabular}

Mann-Whitney $U$ Test is a nonparametric statistical test which was carried out to measure the differences on the four OLC dimensions (organizational culture and leadership) between genders. Table 5 shows the summary statistics of Mann-Whitney $U$ Test. The Z-value for organizational culture $(-2.373)$ is significant at $5 \%$ level $(p=0.018<0.05)$. Specifically, female perception is higher than male (25.76 against 16.20) that organizational culture took place in their organization. It is concluded, therefore, that male and female respondents differ in their perception on organizational culture in their organization. However, there is no difference in the perception of respondents on leadership regardless of their gender $(p>0.05)$. 
INTERNATIONAL JOURNAL OF ACADEMIC RESEARCH IN PROGRESSIVE EDUCATION AND

DEVELOPMENT

Vol. 7, No. 3, July 2018, E-ISSN: 2226-6348 @ 2018 HRMARS

\section{Comparing Perceived Organizational}

\section{Culture and Leadership among Respondents of Different Educational Level}

Table 6: Summary Statistics of Kruskal-Wallis Test among Respondents with Different Educational Level

\begin{tabular}{lll}
\hline Test Statistics & Organizational Culture & Leadership \\
Mean Rank: Bachelor Degree & 22.75 & 23.27 \\
Mean Rank: Master Degree & 22.70 & 23.03 \\
Mean Rank: PhD & 19.33 & 13.17 \\
Chi-Square & 0.201 & 1.793 \\
p-value & 0.904 & 0.408 \\
\hline
\end{tabular}

*Significant at 0.05

Table 6 shows the summary statistics of Kruskal-Wallis Test on the two OLC dimensions (organizational culture and leadership) among respondents with different educational level. There is no evidence of statistically significant difference $(p>0.05)$ in the perception on organizational culture and leadership being practiced in the organization among respondents with different educational level. Thus, it is concluded that the perception on organizational culture and leadership among respondents do not differ regardless of their educational level.

\section{Conclusion}

This study concludes that respondents had positive perceptions on organizational culture and leadership as factors of organizational learning capabilities in their organization. The findings revealed that the culture of practicing successful learning of other departments and organization are being followed and employees are encouraged to apply the culture of contributing new ideas in their organization. It can be assumed that the library has realized the importance of learning culture in their organization. When organization embedded good organizational culture within their organization it will give good impact to all their employees. Culture in organization provides elements of appreciation and growth of positive action within organizational system (Jenlink \& Banathy, 2005).

On top of that, the leaders are open to change new ideas, have the skills of sharing knowledge and that leaders always involved employees in making important decision. Leadership is important in an organization and in the library, the leaders play a major role in order to cultivate learning culture in the organization. Shoid and Kassim (2013) asserted that a constant and powerful leadership will encourage employees to do their job efficiently because they want to enhance and develop learning culture.

Thus, it can be assumed that the library practiced organizational culture to encourage their employees to share new ideas or knowledge among them so that they can have better understanding about their organization functionality. Moreover, there was evidence of difference regarding organizational culture in terms of gender. This implied that employees do not equally acknowledged the organizational culture in the library. 


\section{INTERNATIONAL JOURNAL OF ACADEMIC RESEARCH IN PROGRESSIVE EDUCATION AND DEVELOPMENT}

Vol. 7, No. 3, July 2018, E-ISSN: 2226-6348 @ 2018 HRMARS

This study had its limitation. The study was based on data from only one library, hence the result should not be generalized to other libraries. In future, this study should use a larger representative sample from other libraries in Malaysia. The items in the instrument should include other dimensions of learning organization practices. Other than that, demographic information can be compared between age, work experience and other demographic characteristics.

\section{References}

Chiva, R. \& Alegre, J. (2005). Organizational learning and organizational knowledge towards the integration of two approaches. Management Learning, 36(1), 49-68.

Chiva, R. \& Alegre, J. (2008). Emotional intelligence and job satisfaction: The role of organizational learning capability. Personnel Review, 37(6), 680-701.

Chiva, R. \& Alegre, J. (2009). Organizational learning capability and job satisfaction: An empirical assessment in the ceramic tile industry. British Journal of Management, 20(3), 323-340.

Chiva, R., Alegre, J. \& Lapiedra, R. (2007). Measuring organizational learning capability among the workforce. International Journal of Manpower, 28(3), 224-42.

DePree, M. (1989). Leadership is an art. New York: Dell Publishing.

Goh, S. \& Richards, G. (1997). Benchmarking the learning capability of organizations. European Management Journal, 15(5), 575-583.

Goh, S. C. (2003). Improving organisational capability: Lesson from two case Studies. Learning Organization, 10(4), 216-227.

Hishamudin et al. (2010). Learning organisation elements as determinants of organisational performance of non-profit organisations (NPOs) in Singapore, International NGO Journal, 5(5), 117-128.

Jenlink, P. M. \& Banathy, B. H. (2005). Dialogue: Conversation as culture building and consciousness evolving, in Banathy, B. H. and Jenlink, P.M. (Eds.) Dialogue as a Means of Collective Communication. New York: Kluwer Academic Publisher.

Jerez-Gomez, P., Cespedes-Lorente, J., \& Valle-Cabrera, R. (2005). Organizational learning capability: A proposal of measurement. Journal of Business Research, 58 (6), 715-725.

Kassim, N. A. \& Shoid, M. S. M. (2013). Organizational learning capabilities and knowledge performance in Universiti Teknologi MARA (UiTM) Library, Malaysia. World Applied Sciences Journal, 21(1), 93-97. 
Vol. 7, No. 3, July 2018, E-ISSN: 2226-6348 @ 2018 HRMARS

Khalib, L. H., Kassim, N. A., Ghazali, F. I., Jaafar, N. \& Idris, A. (2015). Organizational Learning Capabilities (OLC) Toward Job Satisfaction: A Conceptual Framework. Academic Research International, 6(2), 169-180.

Neefe, D. O. (2001). Comparing levels of organisational learning maturity of college and university participating in traditional and non-traditional. Madison: University Of Wisconsin-Stout Menomonie.

Northouse, P. (2007). Leadership theory and practice. Thousand Oaks, CA: Sage Publications.

Rowley, J. (2000). Is Higher Education ready for knowledge management? The International Journal of Educational Management, 14(7), 325-333.

Shoid, M. S. M. \& Kassim, N. A. (2014a). Exploring the Effect of Organizational Learning Capabilities (OLC) on Knowledge Performance. World Applied Sciences Journal, 29(12), 1544-1549.

Shoid, M. S. M. \& Kassim, N. A. (2014b). Using Regression Analysis on Measuring Organizational Learning Capabilities (OLC) Dimensions. Middle-East Journal of Scientific Research, 19(5), 614-619.

Shoid, M. S. M. \& Kassim, N. A. (2013). Ascertaining Dimensions of Organizational Learning Capabilities (OLC) in Academic Library. International Journal of Academic Research in Business and Social Sciences, 3(7), 546-554.

Shoid, M. S. M. \& Kassim, N. A. (2015). The Relationships between Organizational Learning Capabilities (OLC) Dimensions and Knowledge Performance. In Proceedings of the International Conference of Information Science, Universiti Teknologi MARA, Shah Alam, December 7-8, 2015. (pp. 151-155).

Shoid, M. S. M., Kassim, N. A. \& Salleh, M. I. M. (2011). Organisational learning capabilities (OLC) towards knowledge performance of librarians: A research model. In Proceedings of the 8th International Conference on Intellectual Capital, Knowledge Management and Organisational Learning (ICICKM), Bangkok, Thailand, Oct 27-28, 2011.

Skansi, D. (2000). Relation of managerial efficiency and leadership styles-empirical study in Hrvatska elektroprivreda. Management, 5(2), 51-67. 